\title{
Agenda Setting, Public Opinion, and the Issue of Immigration Reform
}

\author{
Johanna Dunaway \\ Department of Political Science \\ Sam Houston State University \\ Huntsville, TX 77341-2149 \\ jdunaway@shsu.edu \\ Marisa A. Abrajano \\ Department of Political Science \\ University of California, San Diego \\ La Jolla, CA 92093-0521 \\ mabrajano@ucsd.edu \\ Regina P. Branton \\ Department of Political Science \\ Rice University \\ Houston, TX 77251-1892 \\ branton@rice.edu \\ September 13, 2007
}




\begin{abstract}
While the importance of agenda setting has been well-documented (Baumgartner and Jones 1995, Iyengar 1991), it is unclear whether its affect holds for issues that may not be salient to a significant portion of the public. We explore this puzzle by examining the issue of illegal immigration, as it is one policy that traditionally impacts those living in states along the U.S.-Mexico border more so than for those residing in non-border states. Our analyses of newspaper coverage of immigration and Gallup public opinion data over a twelve-month period (January-December 2006) provide considerable support for the agenda-setting theory. The volume of news coverage did increase following the protests and as such, the public perceived immigration as an important problem facing the country. These findings hold for individuals residing in both border and non-border states, suggesting that the power of agenda-setting holds across issues that may not be nationally salient to the entire American public.
\end{abstract}




\section{Introduction}

On June 28, 2007 major headlines across the national news reported the death of Senate bill 1639, "The Comprehensive Immigration Reform Act of 2007," which was purported to be the biggest attempt at immigration overhaul in decades. The bill's failure was not due to a lack of effort or attention; the issue of immigration reform, particularly with respect to illegal immigration, began three years earlier with Bush's guest worker program as first proposed in his 2004 State of the Union address. However, all subsequent attempts to pass a bill amenable to both parties in the upper and lower Houses proved to be unattainable. Senator John Kyl (AZ), a co-sponsor on the bill, attributed the local nature of the issue as a key factor in the Bush administration's inability to garner support for the bill. ${ }^{1}$ In fact, a recent New York Times Magazine article, entitled "All Immigration Politics is Local", documents a rural area of Illinois currently embroiled over the issue of immigration. ${ }^{2}$

Over this period of time, though, the issue of immigration reform really rose to national prominence on April 10, 2006, where in cities across the nation, hundreds of thousands of individuals participated in pro-immigrants marches, rallies and protests. This unprecedented response, which can be treated as an "exogenous shock" to the status quo, provides the opportunity to determine whether the mechanism of agenda-setting can be applied to a public policy that, while under the jurisdiction of the federal government, is really a subnational and local issue at its core.

The public's attitudes toward immigration have also traditionally differed for those residing along the U.S.-Mexico border and those living in non-border states. ${ }^{3}$ Extant survey research, which focuses primarily on Anglo attitudes (Leighley 2001; Johnson, Stein and Wrinkle 2003), reveals that individuals residing in border states consistently rate immigra-

\footnotetext{
${ }^{1}$ http://www.npr.org/templates/story/story.php?storyId=11523358.

${ }^{2}$ New York Times Magazine, "All Immigration Politics is Local" by Alex Kotlowitz, August 5, 2007.

${ }^{3}$ See http://www.rasmussenreports.com/2006/July\%20Dailies/Immigration.htm for an example of this pattern.
} 
tion as one of the "most important problems facing the nation," relative to individuals residing in non-border states. However, with the recent increase in national media attention towards immigration reform and the wave of immigration protests nationwide, national public opinion regarding immigration rivaled the level of concern typically expressed by individuals residing in border-states. 4 For example, an April 3, 2006 Lake Research and Terrance Group poll asked a national sample of respondents about the ten most important issues facing the country. Illegal immigration was ranked sixth, with only $8 \%$ of respondents considering it as the biggest concern. ${ }^{5}$ But according to a CBS poll released the day after the pro-immigration rallies, April 11, 2006, national respondents ranked immigration as the third most important problem facing the country, immediately following the war on Iraq and the economy. Thus, while the issue of immigration flows in and out of both the public's and the media's agenda nationally, news coverage and public opinion regarding immigration may be fairly consistent in border-states.

These recent events raise several research questions of interest to those studying the relationship between the news media and public opinion. Does agenda-setting operate in the same way for an issue that is primarily of local concern and salience? Is immigration a more immediate concern to those residing in the border-states and if so, what explains the geographic difference in policy preferences? Previous efforts at contextual explanations offer mixed results (for example Citrin, et al 1990; Tolbert and Hero 1998, 2001; Johnson, Stein and Wrinkle 2003; Valenty and Sylvia 2004), leaving much unexplained about border-proximate public opinion on immigration. What about news coverage? Are the news coverage patterns of immigration offered by local outlets in border-states different when compared to that of the media in other parts of the U.S.? Is media attention to the issue related to fluctuations in public opinion regarding the importance of the issue?

\footnotetext{
${ }^{4}$ See http://www.rasmussenreports.com/2006/State\%20Polls/senateImmigrationBill.htm for a discussion.

${ }^{5}$ Refer to http://www.nationaljournal.com
} 
Despite the fact that immigration may be more salient to those living in border-states than for those who do not, the pro-immigrant rallies brought this issue to the forefront of the national debate. As the theory of agenda setting asserts, the news media can show the public what is important by giving more salience to certain events and issues more than others (Baumgartner and Jones 1995; Iyengar 1991). We build on the agenda setting literature to outline expectations regarding news coverage of and pubic opinion towards immigration in 2006. First, we expect that greater attention by the media to this issue will result in the American public perceiving immigration as a more important problem facing the country in the time-period immediately surrounding and following the protests. Second, we argue that local media in border-states consistently offer more coverage of immigration and immigration issues than will the mainstream media. We contend that the salience of immigration in border-states is partly due to the steady stream of coverage given to the issue by local media outlets (Branton and Dunaway 2005). Third, we expect that public opinion over the issue fluctuates for both non-border and border state populations, but we also expect border level concern over immigration to be consistently higher than that of non-border respondents.

We test these contentions by examining media coverage of immigration as well as public opinion towards immigration over a twelve-month period (January-December 2006). We examine newspaper coverage of immigration from states along the U.S.-Mexico Border (e.g San Diego Union Tribune) as well as those from non-border states (e.g. Atlanta JournalConstitution). Altogether, we examine all 2006 coverage of immigration in twenty-four different newspapers. We then analyze Gallup public opinion poll data for this same time period to determine which issues the public perceived as being of greatest concern at different points in time. If agenda-setting was indeed taking place, then we should see a correspondence between periods with a high volume of immigration coverage and public opinion ranking immigration as one of the most important problems facing the country. Indeed, public opinion 
polls, the news coverage trend data, as well as our cross-sectional time series analysis lend considerable support for the agenda-setting hypothesis. Following the protests, the volume of newspaper coverage on immigration increased dramatically, along with an increase in public concern over the issue of immigration. These findings provide us with a number of insights on the power of agenda-setting to influence the public's opinions on policies that are both local and national in scope.

In the next section, we review the literature on agenda setting and news coverage, along with a discussion of our hypotheses. We then go over the data and methods used to test these hypotheses, and then present our results and findings. The final section places these findings in the context of the existing literature on agenda setting, public opinion, and the media.

\section{Agenda Setting and Public Opinion}

The agenda setting literature demonstrates the effect of prominent media attention on the weight the public gives to certain issues (Iyengar and Kinder 1987; Baumgartner and Jones 1995). Agenda setting describes the process by which the news media shows the public what is important by giving more salience to certain events and issues more than others. Because of increased media attention, specific issues are more salient in the minds of citizens. As a result, the public perceives those issues which receive the majority of media coverage to be the ones of greatest importance (McCombs and Shaw 1972; Baumgartner and Jones 1995; Zaller 1996). This implies that heightened coverage of any issue will increase the likelihood that the public perceives this issue to be important.

The research on information processing also suggests that media cues about certain issues or events play a large part in what we consider to be important. Accessibility in the mind significantly influences the way we evaluate issues (Zaller 1992). Because we are cognitively 
limited, we organize concepts thematically, and can only retain a finite number of important considerations in the forefront of our minds. When queried about issues or opinions, it is from these immediate set of considerations that one's response is generated. Therefore, even when an issue is not a daily or immediate concern to us, constant media attention to a particular issue primes our awareness of the issue and our weight of the issue by making it more accessible in our mind or increasing the importance we attach to the issue (Nelson, Clawson, and Oxley 1997; Lau and Redlawsk 2001). With respect to immigration, high volumes of media attention may prime awareness or concerns about this issue to the mass public. According to agenda-setting theory, the heightened media coverage may cause immigration to be more salient in areas closer to the border, and may explain some of the variation in attitudes between those residing in border-states and those residing elsewhere in the United States. Specifically, we expect those residing in border-states to be more frequently exposed to news coverage regarding immigration, and to be more likely to rate immigration as a "most important problem facing the country." Concerns over the direction of causality, though, are alleviated with the "exogenous shock" that occurred over the course of this twelve-month period - the nationwide protests. Since this event generated such a significant amount of media attention, it helps to neutralize previous dispositions on this issue since it truly gained national status following the protests.

Several studies have also demonstrated the way the national public policy agenda fluctuates with the volume of media attention to particular issues (Baumgartner and Jones 1995; Kingdon 1995). Public opinion and congressional action on issues such as nuclear energy, tobacco use, pesticides, and urban affairs track closely with media attention to these issues (Baumgartner and Jones 1995). As such, there is every reason to expect that with increased media attention, the immigration issue will emerge in the same way as a "most important policy problem" in the public mind. Additionally, the agenda-setting effect of the media should operate for residents of border states as well as non-border states. 
Hypothesis 1: Respondents will be most likely to rank immigration as a most important problem when the media are giving the matter significant attention.

\section{Variations in Public Opinion Towards Immigration}

There are several reasons to expect attitudes toward immigration to be different among border-state and non-border state residents. Two perspectives, offered by literatures on inter-group conflict and inter-group contact, suggest an explanation based on ethnic context. Border communities typically have higher concentration of immigration populations, which could influence border residents' perceptions of immigrants and immigration. However, as noted previously, the extant literature on the subject provides only mixed evidence as to the effect of context on attitudes toward minority groups (Citrin, et al 1990; Tolbert and Hero 1998, 2001; Johnson, Stein and Wrinkle 2003; Valenty and Sylvia 2004). Others suggest that geographic proximity to the border may have an independent effect on immigration attitudes. These scholars argue that physical environmental cues such as border check points, wire fences, and warning signs operate to increase perceptions of threat and competition from immigrants, while residents distant from the border may not be continually exposed to such first-hand images (Cornelius 1882; Books and Prysby 1991). Finally, Branton et. al (2007) argue that along with environmental cues, cues from the local media may influence perceived threat regarding immigrants.

An individual's source for information may also influence his/her attitudes towards a policy issue. A well-known relationship exists between proximity of events and the selection of stories covered by local news; thus events that occur "close to home" receive more coverage than events occurring farther away (Adams 1986; Bendix and Liebler 1999; Martin 1988; Molotch and Lester 1975). A primary reason for this is that coverage of local issues garners better ratings for local news organizations (McManus 1994; Hamilton 2004). Local media 
outlets understand that their profit depends on meeting the preferences of their geographic market and its audience. This is because individuals are interested in the events that occur in their surrounding community (Hamilton 2004). In fact, in recent years, a well documented trend toward audience preference for local news over national news exists (Fowler et. al 2007). ${ }^{6}$ Thus, local media outlets should focus on stories that are both sensational and of broad interest to consumers in the surrounding areas; immigration news stories are a particularly good fit in media markets located in border-states.

Furthermore, extant research suggests that the volume and substance of media coverage of immigration varies according to the spatial location of the media organization (Branton and Dunaway xxx) and according to the language in which it is offered (Leighley 2001; Johnson, Stein and Wrinkle 2003). ${ }^{7}$ Other scholarly work indicates that (irrespective of ethnic context) policy attitudes regarding immigration are affected by one's proximity to the border (e.g. Alvarez and Butterfield 2000; Branton et. al 2007), and that significantly more news coverage of immigration exists in areas proximate to the border than the news coverage in areas further removed from the border (Branton and Dunaway xxx). Based on this research, we argue that media cues regarding immigration are far more prevalent in the border-states than for non-border states in the U.S.

Hypothesis 2: Local media in border-states consistently offer more coverage of immigration than local media in non-border states.

As outlined above, respondents residing in border-states may be more likely to rate

\footnotetext{
${ }^{6}$ A 1988 analysis of Nielsen data found that the national network news broadcasts reached 47 million viewers nightly, while local news broadcasts reached an estimated 80 million (McManus 1994). According to Graber (2002), television is the most trusted and primary source of information for the average American. And it is important to note that this is in light of the citizen preference for local news. In short, citizens trust the local news as the information they use in making political and social judgments.

${ }^{7}$ Branton and Dunaway (xxx) demonstrate that media coverage of immigration increases with proximity to the border due to the economic motivations of local media outlets. Specifically, efforts to increase audiences lead to local outlets focusing on the most sensational and most local issues possible. Being proximate to a volatile geographic boundary such as the U.S. Mexico border prompts local news outlets to produce a disproportionate amount of news stories that focus on the negative aspects of immigration and other borderrelated issues.
} 
immigration as an important problem than are those residing in non-border states. Previous research makes the distinction between obtrusive and unobtrusive issues. Issues are obtrusive when most members of the public have dealt with them directly. Issues are unobtrusive if audience members have not had direct experience with the issue (Demers et al, 1989). This implies that the agenda setting effect of the media should be strongest when audiences have no direct experience with the issue. In these cases information is not derived from direct experience, but through direct or indirect exposure to media messages regarding the issue. Since border issues are unobtrusive (not of immediate daily concern) to those residing further from the border, national media attention to the issue may be particularly important to the salience of the issue in these areas. Generally speaking, we expect non-border respondents to be less likely to rank immigration as a most important problem. But if the news media is giving significant attention to immigration, then we expect the opinions of non-border residents to be similar with those living in border states.

Hypothesis 3: Non-border respondents will be less likely than border-respondents to rank immigration as a most important problem, unless the media is giving the matter significant attention.

In the next section, we present the research design, data and methods used to test these three hypothesis. We then present our findings and discuss them in the context of the existing work in this area.

\section{Research Design, Data, and Analysis}

Over the last eighteen months, dramatic and salient events intermittently occurred surrounding over the issue of immigration. Notable incidents such as the congressional debates and mass immigration protests generated a spike in media attention to the issue of immigration. This provides the setting for a quasi-experimental design where we can examine the impact 
of media coverage on public opinion toward immigration. To determine the relationship between media coverage of immigration and public opinion toward immigration, we rely on two key sources of data: content analysis of newspapers and 2006 Gallup Public Opinion surveys. These data allow us to assess media coverage trends of immigration from JanuaryDecember 2006. Additionally, the data enables us to examine whether public perception of immigration varies in relation to media coverage on immigration.

Our first set of analyses involves a content analysis of several major metropolitan newspapers on the issue of immigration. Using an on-line newspaper archive, ${ }^{8}$ we constructed a data set indicating the number of immigration-related newspaper articles printed by month for each newspaper between January 1, 2006 and December 31, 2006. The sample of newspapers analyzed include: the Albuquerque Journal, Arizona Republic, Atlanta Journal-Constitution, Charlotte Observer, Cleveland Plain Dealer, Detroit Free Press, El Paso Times, Los Angeles Times, Milwaukee Journal Sentinel, Oklahoma City Oklahoman, Minneapolis Star-Tribune, Dallas Morning News, Houston Chronicle, Miami Herald, New York Times, USA Today, Washington Post, Boston Globe, Chicago Tribune, Las Vegas Review-Journal, Philadelphia Inquirer, San Diego Union Tribune, San Francisco Chronicle, and The Portland Oregonian. ${ }^{9}$ Again, this newspaper-level data provide national trends in coverage on immigration by month during the observed time-period, which is the focus of $\mathrm{H}_{1}$. Additionally, this sample of newspapers can assess whether differences exist in the coverage between media outlets located in border states and non-border states, the primary contention of $\mathrm{H}_{2}$.

\footnotetext{
${ }^{8}$ We utilized America's Newspapers database provided by Newsbank, Inc and LEXIS/NEXIS. These resources provide the most extensive full-text archives of newspapers currently available.

${ }^{9}$ The newspapers included in this study were selected based on two factors. First, we selected newspaper from the fifty largest cities in the United States. Second, we narrowed our sample of newspaper to include outlets located in border and non-border states. The border state newspapers include: Albuquerque Journal, Arizona Republic, El Paso Times, Los Angeles Times, Dallas Morning News, Houston Chronicle, Miami Herald, San Diego Union Tribune, and the San Francisco Chronicle. The Miami Herald is included among the "border-state" newspapers due to the fact that Florida has one of the largest foreign born populations in the United States. Note however, that this characterization does not change the pattern of either the news coverage or the public opinion trend.
} 
The second set of analyses uses monthly Gallup opinion polls from 2006 to examine public opinion on immigration. We selected this public opinion data for two reasons that are key to the execution of our analysis. First, each monthly survey conducted in 2006 queries respondents on what they perceive to be the most important problem facing the country. The Gallup Poll's "Most Important Problem" $(M I P)$ question makes it possible to examine monthly shifts in public opinion regarding the importance of immigration relative to other major policy issues in the United States. Second, the Gallup opinion polls include geographic identifiers that indicate the state in which each respondent resides. We use this information to evaluate general differences in immigration attitudes and differences among individuals residing in border versus non-border states, the bases of $\mathrm{H}_{1}$ and $\mathrm{H}_{3}$.

Our dependent variable for our multivariate analysis is the MIP question. In each of the 2006 monthly Gallup polls, respondents are asked "What is the most important problem facing this country today?" This is phrased as an open-ended question and we create a dichotomous variable, MIP, which is coded "1" if a respondent identifies immigration as one of the most important problems facing the nation and " 0 " if otherwise. ${ }^{10}$ (See Appendix A for descriptive statistics on this covariate.) The analysis presented in this study is limited to white, non-Latinos for a practical reason. The Gallup data includes far fewer non-white respondents, making it difficult to accurately and completely assess the questions of interest for these racial and ethnic groups.

Our first independent variable of interest pertains to media coverage of immigration. Generally speaking, we argue that as media attention devoted to immigration increases, the public's perception of the importance of immigration likewise increases. To empirically evaluate this proposition we construct two measures of media coverage of immigration. First, we construct a continuous measure, Avg. \# Articles, which indicates the average number

\footnotetext{
${ }^{10}$ The Gallup polls ask what is the most important problem facing the country. The MIP measure indicates whether a respondent names immigration as one of the most important problems.
} 
of articles regarding immigration published per month across all the newspapers content analyzed in this study. This measure ranges from 11 to 59 articles published in a given month, with a mean value of 25 articles. Second, we use a three-category measure, Volume Index, which ranges from low coverage ("1") to high coverage ("3") of immigration. This measure is based on the distribution of the Avg. \# Articles measure. Specifically, the index is coded " 1 " when the average number of immigration articles published in a given month falls within the first quartile on the Avg. \# Articles variable; the index is coded " 2 " (reflecting moderate coverage) when the average number of articles published in a month falls between the first and third quartile; and, the index is coded " 3 " when the average number of immigration articles published in a month falls within the third quartile on the Avg. \# Articles measure. The volume index measure is structured to reflect periods when monthly media coverage deviate from periods of typical media coverage of this issue. ${ }^{11}$

The second primary independent variable of interest is Border State, which takes the value of "1" if a respondent resides resides in either Arizona, California, New Mexico, Texas or Florida and "0" otherwise. ${ }^{12}$ We include this variable to discern whether geographic differences exist in individual-level attitudes toward immigration (e.g. Burns and Gimpel 2000). In accordance with $\mathrm{H}_{3}$, we expect respondents who reside in a border state to be more likely to perceive immigration as one of the most important problems facing the nation when compared to respondents who reside in non-border states.

In addition to these two primarily variables of interest, the model also includes a measure

\footnotetext{
${ }^{11}$ For example, the average number of newspaper articles published in February 2006 was 11 ; thus, the volume index measure is coded " 1 " to denote a low level of coverage in this month. Alternatively, the average number of immigration articles published in March of 2006 was 59; thus, the volume index measure is coded " 3 " to denote a high level of coverage.

${ }^{12}$ The models were estimated including Florida as a border state and as a non-border state. Florida is considered by many to be equivalent to a border states in terms of the number of immigrants residing in the state and its unique history with regard to Cuba. Indeed, Florida has the fourth largest foreign born population in the United States. Although, the coefficient on the border state differs slightly when Florida is included as a border state, the nature and level of significance of the relationship between border-state and public opinion does not vary. The results are available upon request from the authors.
} 
of individuals' perceptions of the United States economic status. National Economy is a categorical variable which rates the economic conditions in the United States as follows: "1" poor, "2" only fair, "3" good, and "4" excellent. We control for economic evaluations since one's perceptions of the economy has been associated with the perceived importance of the issue of immigration (Burns and Gimpel 2000; Hood and Morris 1997).

Each of the 2006 Gallup polls include information not only regarding the state of residency for each respondent, but also their county of residence. This geographic identifier offers the opportunity to account for characteristics of the more immediate environment in which each respondent resides. As such, we control for a county-level contextual indicator, Foreign Born, which reflects the percent of each county's population that is foreign born. ${ }^{13}$ Individuals residing in areas with a sizable foreign born population may be more likely perceive immigration as one of the nation's most important problems than individuals residing in areas with a smaller foreign born population. The extant literature suggests that the percentage of foreign born individuals residing in an area negatively influences one's attitudes towards immigration (Hood and Morris 1998).

The models also include a series of individual-level control variables: age, sex, education, partisan affiliation, and political ideology. Age is a continuous variable, ranging from low to high. This variable is included based on previous findings which suggest that individuallevel age is associated with attitudes toward immigrants and immigration policy (e.g. Hoskin and Mishler 1983; Espenshade and Calhoun 1993). Additionally, Espenshade and Calhoun (1993) find gender differences in individual-level immigration attitudes; thus, the models account for the gender of respondents. A respondent's sex is represented by Female, which is coded " 1 " if a respondent is female and " 0 " if a respondent is male. Extant research also indicates that as individual-level education increases, the likelihood of supporting re-

\footnotetext{
${ }^{13}$ The observed value of the foreign born measure ranges from .42 to 50.9 percent. The mean value of percent foreign born is 8.2 .
} 
strictive immigration policies decreases (Citrin, et al. 1997; Hood and Morris 1998; Hoskin and Mishler 1983). Therefore, to account for potential educational effects, the models includes control for individual-level education status. A respondent's level of Education is measured by a categorical variable ranging from "1" to "4" where higher values reflect a greater level of educational attainment. Moreover, existing public opinion research suggests that individual-level partisanship and ideology are associated with attitudes toward immigrants and immigration related policy issues.(Citrin, Reingold, and Green 1990; Citrin et al. 1997; Hood and Morris 1997; Hood and Morris 1998). Thus the models include a series of binary indicators to account for a respondent's partisan affiliation and ideology. Political ideology is measured by two binary indicators: Conservative and Moderate, with the baseline category being those identifying as liberal. A respondent's partisan affiliation is measured by two binary indicators, Republican and Independent, where Democrat serves as the baseline category. Finally, each model includes a series of month dummy variables, with December 2006 serving as the baseline category. We include the month dummy variables to control for variability in factors unaccounted for in the model that may influence the perceived importance of immigration (Beck, Katz, and Tucker 1998). ${ }^{14}$

\section{Public Opinion and Media Coverage of Immigration}

As outlined in $\mathrm{H}_{1}$, we argue that individuals are most likely to identify immigration as one of the country's most important problems as the media's attention to the issue of immigration increases. To evaluate this hypothesis we begin by considering basic descriptive statistics on media coverage of immigration and public attitudes toward immigration presented in Figure 1. The top panel of Figure 1 plots the average number of articles published by month from

\footnotetext{
${ }^{14}$ The models were estimated with and without the temporal dummy variables. The inclusion of these covariates did not impact the direction or significance level of any of the other covariates included in the models. Due to space constraints and a lack of substantive importance, the temporal dummy variable parameter estimates are not presented in the tables.
} 
January-December 2006 among all the newspapers included in our analysis. The bottom panel of Figure 1 plots the proportion of Gallup respondents that identify immigration as one of the most important problems by month. The most striking feature of Figure 1 is the degree to which public attention to immigration and media coverage of immigration move together over time. Most notably, as media coverage of immigration spikes in April of 2006, public perception of immigration as one of the most important problems facing in the nation also surges to the highest level of this twelve month period of time. Indeed, the proportion of respondents perceiving immigration as one of the most important problems increases from approximately 6 percent in March of 2006 to over 21 percent in April 2006. Additionally, as media attention devoted to immigration begins to recede after June 2006, the proportion of respondents identifying immigration as the most important problem likewise begins to decline.

[Figure 1 Here]

Next, we empirically evaluate the relationship between media coverage of immigration and individual-level attitudes regarding the importance of immigration. Table 1 presents the logistic regression results for the models predicting individual-level perception of immigration as the most important problem facing the nation. ${ }^{15}$ The first column contains the estimates that account for media attention to immigration using the Volume Index measure; the third column presents the results for the model including the Avg. \# Articles measure.

[Table 1 Here]

The parameter estimates on both measures of media coverage are positively and significantly related to individual-level ratings of immigration as the most important problem. Substantively, this indicates that as media attention given to immigration increases, the

\footnotetext{
${ }^{15}$ The multilevel nature of data can present problems due to serial dependence within clusters and heteroskedasticity across clusters. Thus, we utilize the Huber/White/sandwich estimation (Huber 1967), which adjusts the variance-covariance matrix to correct for heteroscedasticity and serial dependency posed by the use of multilevel data.
} 
probability of individuals identifying immigration as one of the nation's most important problems likewise increases; this confirms our expectations presented in $\mathrm{H}_{1}$. A one unit increase on the volume index leads to a 120 percent increase in the odds that an individual will identify immigration as one of the most important problems. More specifically, as the volume of media coverage of immigration increases from low to high on the volume index measure, the probability of identifying immigration as one of the MIPs increase from .06 to .24. Furthermore, with every one unit increase in the average number of articles published on immigration per month, the odds of identifying immigration as one of the MIPs increases by 4.5 percent. To place this into context, with every one standard deviation increase in the average number of articles published per month (approximately 14 articles), the odds of identifying immigration as one of the MIPs facing the nation increases by 87 percent. These estimates demonstrate that media attention towards immigration influences public perception of the importance of this issues. Therefore, at the peak of immigration coverage in 2006, public concern over immigration was also likely to be at its pinnacle.

Next we consider differences in coverage devoted to the issue of immigration between media outlets located in border versus non-border states. As stated in $\mathrm{H}_{2}$, we contend that media outlets in border states should offer more coverage of immigration than media outlets located in non-border states. Figure 2 presents a graph of media coverage of immigration provided by media outlets located in border and non-border states. This graph plots that average number of articles published by month between January and December 2006 for the sample of newspapers content analyzed in this study, differentiated by border location. ${ }^{16}$

[Figure 2 Here]

As Figure 2 clearly demonstrates, media outlets in border states offer a higher volume of

\footnotetext{
${ }^{16}$ Given that individuals in border and non-border states may be exposed to national news such as the USA Today, the graph contains only non-national newspapers. Yet, even when the coverage of this national newspaper is factored into this graph, the trend in coverage and the regional differences remain the same. This graph is available from the authors upon request.
} 
average coverage of immigration than media outlets located in non-border states. Moreover, we see a dramatic increase in the amount of media coverage towards immigration during the time period of the mass immigration rallies in (April 2006); this holds for media outlets located in both border and non-border states. However, media outlets in border states offered more coverage during the apex of media coverage of immigration in April and May of 2006 than did non-border media outlets. They also published a greater number of stories on immigration in the months before and after this surge. To empirically test $\mathrm{H}_{2}$ we calculate a simple t-test comparing the average number of articles published by border and non-border states during 2006. ${ }^{17}$ This test indicates a statistically significant difference between the mean number of stories published by non-border and border state newspapers $(\mathrm{t}=-2.73, \mathrm{p}=$ .007). Substantively, this indicates that non-border state media outlets publish significantly less articles on immigration than border-state media outlets.

To this point, we have established that when the media devotes greater attention to immigration, the public is more likely to identify immigration as one of the nation's most important problems. Additionally, we have demonstrated how media outlets in border states publish a higher volume of immigration stories than media outlets in non-border states. This leads us to the last of our hypotheses; in $\mathrm{H}_{3}$, we propose that individuals residing in border states are more likely to rank immigration as one of the MIP than non-border residents. We test this hypothesis by re-estimating the models presented in Table 1 and this time, we include a variable denoting whether a respondent resides in a border or non-border state. These models are presented in Table 2. Again, the first column presents the estimates for the model including the Volume Index measure, while the third column contains the results for the model including the Avg. \# Articles measure.

\footnotetext{
${ }^{17}$ In addition to the t-test, we also estimated a statistical model of media coverage for the sample of newspapers content analyzed in this study. The poisson regression results are consistent with Figure 2 and the simple t-test. These results indicate that media outlets in border states published significantly more articles on immigration per month than media outlets in non-border states. The results are available from the authors.
} 


\section{[Table 2 Here]}

The parameter estimates in both models indicate that residing in a border state is positively and significantly associated with identifying immigration as one of the MIPs facing the nation; this lends considerable support for $\mathrm{H}_{3}$. Indeed, the odds of indicating immigration as an important problem is approximately 26 percent higher for border than for non-border state respondents. As such, even after controlling for variability in media coverage of immigration, border state residents exhibit a heightened level of concern regarding immigration. The estimates also indicate that even after controlling for the geographic location of a respondent, media coverage of immigration is associated with public attention given to the issue of immigration. A one unit increase on the volume index leads to a 120 percent increase in the odds that an individual will identify immigration as one of the most important problems. Furthermore, with every one unit increase in the average number of articles published on immigration per month, the odds of identifying immigration as one of the MIPs increases by 4.5 percent.

To further illustrate the impact of residing in a border state and media coverage of immigration, we calculate predicted probabilities. ${ }^{18}$ The probability that an individual who resides in a border state identifies immigration as the MIP increases by .10, from .17 to .37 , as media coverage increases from low to high on the volume index measure, while the probability among individuals residing in non-border states increases by a lager amount, .18 (from .14 to .32). Additionally, the probability that an individual residing in a border state identifies immigration as the MIP increases from .14 to .36 as the average number of articles published per month increases from the lowest to the highest value (a difference of $.12)$; and the probability among individuals residing in non-border states increase from .12 to .31 (a difference of .19). Regardless of the media variable used, an increase in media

\footnotetext{
${ }^{18}$ The following scenario is used to estimate predicted probabilities: an average-aged, moderate-republican, male, with some college experience, rates the U.S. economy as "only fair," with county-level percent foreignborn set to the mean.
} 
coverage has a larger impact on an individual's likelihood of citing immigration as the MIP for those residing in non-border, as opposed to border, states. This difference is consistent with the distinction between obtrusive and non-obtrusive issues. Because media coverage of immigration in border states is consistently higher than it is for non-border states, an increase in media coverage may do little to increase individuals' attitudes toward immigration for those residing in border states. However, since those living in non-border states are not exposed to as much immigration coverage and because immigration is not a daily or immediate concern to them, a small increase in media exposure may have a greater impact on their attitudes and perceptions than those living in border states. One might argue that increases in media coverage of immigration or levels of perceived threat might occur as a result of an increase in illegal activities brought on by an influx of illegal immigrants. Though we do not present the data here, in other work we test this by compiling Department of Justice crime statistics and find no relationship between local crime levels and foreign born populations or increased media coverage of immigrant related issues.

Before concluding, we would like to briefly discuss some additional results relating to other independent variables in the models. First, the results indicate the odds of identifying immigration as one of the MIPs is 169 percent higher for a conservative and 55 percent higher for a moderate when compared to a liberal. Likewise, the odds of an individual identifying immigration as one of the MIPs is 102 percent higher for a Republican and 89 percent higher for an independent when compared to a Democrat. Second, as respondent age increases the likelihood of identifying immigration as one of the most important problems facing the nation increases. In fact, with a one standard deviation increase in age, there is a 25 percent increase in the odds of an individual citing immigration as an important problem. Third, more highly educated individuals are less likely to identify immigration as a concern. The odds of an individual with some college education citing immigration as the MIP is 13 percent lower when compared to an individual with a high school degree or less. 
This finding likely reflects perceived competition or threat among less affluent and/or blue collar individuals.

Finally, the estimates indicate that as the percentage of the foreign born population increases in one's country, the likelihood that an individual identifies immigration as one of the MIP likewise increases. Consistent with the inter-group conflict literature, in areas with a larger foreign-born population the perceived threat or competition posed by immigration may be higher than in areas with a smaller foreign born population. This results in heightened concern over the issue of immigration.

\section{Conclusion}

This research is important as it provides a timely opportunity to contribute to the existing literature on media effects, public opinion, and agenda setting. The manner in which immigration surged into the national headlines in 2006 provides the opportunity to empirically evaluate the connection between shifts in media coverage and public opinion towards a highly controversial issue. We found that, consistent with the agenda setting theory, heightened media coverage towards the issue of immigration led to a heightened perception amongst the American public that immigration was an important policy concern facing the nation. Moreover, we find regional variation in the amount of media coverage devoted to immigration; consistent with previous research, the volume of immigration coverage in border states is significantly greater than the amount of immigration coverage in non-border states. But despite this variation, the amount of media coverage focusing on immigration reform increased for both border and non-border states following the April 10, 2006 protests. Thus, this momentous event caused media outlets nationwide to cover this issue to a greater extent than it did so in the past.

Although immigration is inherently a local issue in the sense that some communities (e.g. 
border states) are more affected by it than others (e.g. non-border states), the way in which the media devoted such a considerable amount of attention to this issue brought it to the forefront of the national policy agenda. In turn, this resulted in the public's perception of the issue to be one of the most important problems facing the country. We are also able to alleviate concerns over the direction of causality as the marches and rallies of April 2006 led to a significant and almost equal amount of national media coverage towards immigration; so even if those living in border states are inherently more concerned with immigration than those residing in non-border states, leading to more media coverage of this issue, the exogenous shock of these marches and protests onto the political landscape made it so that the entire public became aware of the issue.

Our analyses of both the public opinion polls and print media over a twelve-month period contribute to the political communication research and research on public opinion in several ways. First, we show how an issue of local salience can easily become one of national concern, as a result of the amount of attention the media devoted to the issue. These findings confirm the previous research on agenda setting, and also contribute to this literature by examining how a local issue can become the focus of national attention. Furthermore, this research holds real-world implications by demonstrating how the media can influence the political views and attitudes of the American public, particularly on an issue that may not be on the radar for many Americans. Thus, despite the continuing debate over the media's ability to influence public opinion, in the case of immigration, the media's attention to this controversial policy helped to shape public sentiments on this topic. 


\section{References}

[1] Adams, William. 1986. "Whose Lives Count?: TV Coverage of Natural Disasters." Journal of Communication, 36: 113-122.

[2] Alvarez, Michael and Tara Butterfield. 2000. "The Resurgence of Nativism in California? The Case of Proposition 187 and Illegal Immigration." Social Science Quarterly 81: 16779 .

[3] Baumgartner, Frank R. and Bryan D. Jones. 1995. Agendas and Instability in American Politics. Chicago: The University of Chicago Press.

[4] Beck, Nathaniel, Jonathan N. Katz, and Richard Tucker. 1998. "Beyond Ordinary Logic: Taking Time Seriously in Binary-Time-Series-Cross-Section Models." American Journal of Political Science 42: 1260-88.

[5] Bendix, Jacob and Carol Liebler. 1999. "Place, Distance, and Environmental News: Geographic Variation in Newspaper Coverage of the Spotted Owl Conflict." Annals of the Association of American Geography, 89: 658-676.

[6] Books, John W. and Charles L. Prysby. 1991. Political Behavior and the Local Context. New York: Praeger Publishers.

[7] Branton, Regina P. and Johanna Dunaway. n.d. "Spatial Proximity to the US-Mexico Border and Local News Coverage of Immigration Issues." Forthcoming, Political Research Quarterly.

[8] Branton, Regina P., Gavin Dillingham, Johanna Dunaway, and Beth Miller. 2007. "Anglo Voting on Nativist Ballot Initiatives: the Partisan Impact of Spatial Proximity to the Border of Mexico." Social Science Quarterly 88(3) 882-897.

[9] Burns, Peter and James Gimpel. 2000. "Economic Insecurity, Prejudicial Stereotypes, and Public Opinion on Immigration Policy." Political Science Quarterly. 115(2):201-225.

[10] Citrin, Jack, Beth Reingold, and Donald Philip Green. 1990. "American Identity and the Politics of Ethnic Change." Journal of Politics 52:1124-1154.

[11] Citrin, Jack, Beth Reingold, Evelyn Walters, and Donald Green. 1990. "The 'Official English' Movement and the Symbolic Politics of Language in the United States." Western Political Quarterly 43: 535-559.

[12] Citrin, Jack, Donald Green, Christopher Muste, and Cara Wong. 1997. "Public Opinion Toward Immigration Reform: The Role of Economic Motivations." Journal of Politics 59: 858-881. 
[13] Cornelius, Wayne. 1982. "Interviewing Undocumented Immigrants: Methodological Reflections Based on Fieldwork in Mexico and the U.S." International Migration Review 16: $378-411$.

[14] Demers, David, Dennis Craff, Yang-Ho Choi, and Beth M. Pessin. 1989. "Issue Obtrusiveness and the Agenda-Setting Effects of National Network News." Communication Research, 16: 793-812.

[15] Espenshade, Thomas, and Charles Calhoun. 1993. "An Analysis of Public Opinion Toward Undocumented Immigration." Population Research and Policy Review 13: 189224.

[16] Fowler, Erica Franklin, Kenneth M. Goldstein, Matthew Hale, and Martin Kaplan. 2007. "Does Local News Measure Up?" Stanford Law and Policy Review 18:410-431.

[17] Graber, Doris A. 2002. Mass Media and American Politics. Washington D.C.: CQ Press.

[18] Hamilton, James. 2004. All the News That's Fit to Sell: How the Market Transforms Information Into News. Princeton, NJ: Princeton University Press.

[19] Hood, M.V. and I.L. Morris. 1997. "Amigo o Enimigo?: Context, Attitudes, and Anglo Public Opinion Toward Immigration." Social Science Quarterly. 78:309-23.

[20] _-_-_. 1998. "Give Us Your Tired and Your Poor, . . . but Make Sure They have a Green Card: The Effects of Documented and Undocumented Migrant Context on Anglo Opinion Toward Immigration." Political Behavior. 20: 1-15.

[21] Hoskin, Marilyn, and William Mishler. 1984. "Public opinion toward new migrants: A comparative." International Migration 21: 440-462.

[22] Huber, Paul. 1967. "The Behavior of Maximum Likelihood Estimates Under NonStandard Conditions." Proceedings of the Fifth Berkeley Symposium on Mathematical Statistics and Probability 1: 221-233.

[23] Iyengar, Shanto. 1991. Is Anyone Responsible? How Television Frames Political Issues. Chicago: The University of Chicago Press.

[24] Iyengar, Shanto, and Donald R. Kinder. 1987. News That Matters: Television and American Opinion. University of Chicago Press, Chicago.

[25] Johnson, Martin, Robert M. Stein, and Robert Wrinkle. 2003. "Language Choice, Residential Stability, and Voting Among Latino Americans." Social Science Quarterly $84(2): 412-424$.

[26] Kingdon, John W. 1995. Agendas, Alternatives, and Public Policies. Addison-Wesley Longman Press. 
[27] Lau, Richard R., and David P. Redlawsk. 2001. "Advantages and Disadvantages of Cognitive Heuristics in Political Decision Making." American Journal of Political Science. 45(1):951-971.

[28] Leighley, Jan E. 2001. Strength in Numbers? The Political Mobilization of Racial and Ethnic Minorities. Princeton, NJ: Princeton University Press.

[29] Martin, Shannon. 1988. "Proximity of Event as Factor in Selection of News Sources." Journalism Quarterly, 65: 986-89.

[30] McCombs, M.E. and D. Shaw. 1972. "The Agenda Setting Function of the Mass Media." Public Opinion Quarterly. 36: 176-87.

[31] McManus, John H. 1994. Market Driven Journalism: Let the Citizens Beware? Thousand Oaks, CA: Sage Publications.

[32] Molotoch, Harvey, and Marilyn Lester. 1975. "Accidental News: The Great Oil Spill as Local Occurrence and National Event." American Journal of Sociology, 81: 235-260.

[33] Nelson, Thomas, Rosalee Clawson, and Zoe Oxley. 1997. "Media Framing of a Civil Liberties Conflict and Its Effect on Tolerance," American Political Science Review. 91: $567-83$.

[34] Tolbert, Caroline and Rodney Hero. 2001. "Dealing with Diversity: Racial/Ethnic Context and Social Policy Change." Political Research Quarterly. 54: 571-604.

[35] Tolbert, Caroline and Rodney Hero. 1998. "Race/Ethnicity and Direct Democracy: The Contextual Basis of Support for Anti-Immigrant and Official English Measures." In Citizens as Legislators: Direct Democracy in the United States. ed. Bowler, Shaun, Todd Donovan, and Caroline Tolbert. Columbus: Ohio State University Press.

[36] Valenty, Linda and Ronald D. Sylvia. 2004. "Thresholds for Tolerance: The Influence of Racial and Ethnic Population Composition on the Vote for California Propositions 187 and 209." Social Science Journal 41: 433-46.

[37] Zaller, John R. 1992. The Nature and Origins of Mass Opinion. Cambridge: Cambridge University Press.

[38] _-__-_. 1996. "The Myth of Massive Media Impact Revived: New Support for a Discredited Idea." In Political Persuasion and Attitude Change, ed. Diana C. Mutz, Paul Sniderman, and Richard Brody. Ann Arbor: University of Michigan. 
Table 1. Immigration as MIP and Media Coverage of Immigration

\begin{tabular}{|c|c|c|c|c|}
\hline & Coef. (S.E) & $\% \Delta \mathrm{Odds}$ & Coef. (S.E) & $\% \Delta$ Odds \\
\hline \multicolumn{5}{|l|}{ Personal Attributes } \\
\hline Female & $-.296(.069)^{* * *}$ & -.25 .6 & $-.296(.069)^{* * *}$ & -25.6 \\
\hline Age & $.014(.002)^{* * *}$ & 1.4 & $.014(.002)^{* * *}$ & 1.4 \\
\hline Education & $-.145(.032)^{* * *}$ & -13.5 & $-.145(.032)^{* * *}$ & -13.5 \\
\hline Republican & $.716(.107)^{* * *}$ & 104.5 & $.716(.107)^{* * *}$ & 104.5 \\
\hline Independent & $.636(.096)^{* * *}$ & 88.8 & $.636(.096)^{* * *}$ & 88.8 \\
\hline Conservative & $.995(.136)^{* * *}$ & 170.6 & $.995(.136)^{* * *}$ & 170.6 \\
\hline Moderate & $.442(.136)^{* * *}$ & 55.6 & $.442(.136)^{* * *}$ & 55.6 \\
\hline National Economy & $.320(.046)^{* * *}$ & 37.6 & $.320(.046)^{* * *}$ & 37.6 \\
\hline \multicolumn{5}{|l|}{ Contextual Attributes } \\
\hline Percent Foreign Born & $.022(.005)^{* * *}$ & 2.2 & $.022(.005)^{* * *}$ & 2.2 \\
\hline \multicolumn{5}{|l|}{ Media Coverage } \\
\hline Volume Index & $.789(.010)^{* * *}$ & 120.2 & & \\
\hline Avg \# Articles & & & $.044(.004)^{* * *}$ & 4.5 \\
\hline Constant & $-6.592(.364)^{* * *}$ & & $-6.324(.326)^{* * *}$ & \\
\hline Wald $\chi^{2}$ & $731.58^{* * *}$ & & $731.58 * * *$ & \\
\hline $\mathrm{N}$ Cases & 9877 & & 9877 & \\
\hline \multicolumn{5}{|c|}{$\begin{array}{l}{ }^{* *}=p<.001,{ }^{* *}=p<.01,{ }^{*}=p<.05 \text {. The dependent variable is a dichotomous measure where "1" indicates a } \\
\text { respondent identified immigration as the most important issue facing the United States. "Volume Index" Measure } \\
\text { ranges from } 1 \text { to } 3 \text {. "Avg \# Article" measure reflects the average number of articles published by month on immigration. } \\
\text { The coefficient are logit estimates with robust standard errors presented in parenthesis. The column denoted as } \\
\% \Delta \text { Odds gives the percentage change in the odds of identifying immigration as the most important problem for a one } \\
\text { unit change in } x \text {. }\end{array}$} \\
\hline
\end{tabular}


Table 2. Immigration as MIP, Media Coverage of Immigration, and Border Location

\begin{tabular}{|c|c|c|c|c|}
\hline & Coef. (S.E) & $\% \Delta \mathrm{Odds}$ & Coef. (S.E) & $\% \Delta \mathrm{Odds}$ \\
\hline \multicolumn{5}{|l|}{ Personal Attributes } \\
\hline Female & $-.295(.069)^{* * *}$ & -.25 .5 & $-.295(.069)^{* * *}$ & -25.5 \\
\hline Age & $.014(.002)^{* * *}$ & 1.4 & $.014(.002)^{* * *}$ & 1.4 \\
\hline Education & $-.144(.032) * * *$ & -13.4 & $-.144(.032)^{* * *}$ & -13.4 \\
\hline Republican & $.703(.107)^{* * *}$ & 102.0 & $.703(.107)^{* * *}$ & 102.0 \\
\hline Independent & $.634(.096)^{* * *}$ & 88.6 & $.634(.096)^{* * *}$ & 88.6 \\
\hline Conservative & $.990(.135)^{* * *}$ & 169.1 & $.990(.135)^{* * *}$ & 169.1 \\
\hline Moderate & $.440(.136)^{* * *}$ & 55.2 & $.440(.136)^{* * *}$ & 55.2 \\
\hline National Economy & $.317(.046)^{* * *}$ & 37.3 & $.317(.046)^{* * *}$ & 37.3 \\
\hline \multicolumn{5}{|l|}{ Contextual Attributes } \\
\hline Percent Foreign Born & $.016(.006)^{* *}$ & 1.6 & $.016(.006)^{* *}$ & 1.6 \\
\hline Border State & $.231(.114)^{*}$ & 25.9 & $.231(.114)^{*}$ & 25.9 \\
\hline \multicolumn{5}{|l|}{ Media Coverage } \\
\hline Volume Index & $.788(.010)^{* * *}$ & 119.8 & & \\
\hline Avg \# Articles & & & $.044(.004)^{* * *}$ & 4.5 \\
\hline Constant & $-6.563(.353)^{* * *}$ & & $-6.296(.323)^{* * *}$ & \\
\hline Wald $\chi^{2}$ & $735.62^{* * *}$ & & $735.62^{* * *}$ & \\
\hline N Cases & 9877 & & 9877 & \\
\hline $\begin{array}{l}{ }^{* * *}=p<.001,{ }^{* *}=p<.01,{ }^{*} \\
\text { respondent identified immigrat } \\
\text { ranges from } 1 \text { to } 3 . \text { 'Avg \# Arti } \\
\text { The coefficient are logit estim } \\
\% \Delta \text { Odds gives the percentage } \\
\text { unit change in } x \text {. }\end{array}$ & $\begin{array}{l}05 \text { The dependent va } \\
\text { the most important is } \\
\text { easure reflects the averag } \\
\text { ith robust standard er } \\
\text { in the odds of identifvi }\end{array}$ & 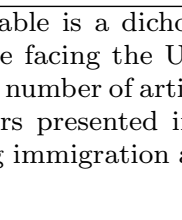 & $\begin{array}{l}\text { mous measure where } \\
\text { ed States. "Volume I } \\
\text { s published by month } \\
\text { parenthesis. The colu } \\
\text { the most important pr }\end{array}$ & $\begin{array}{l}\text { " indicates a } \\
\text { lex" Measure } \\
\text { immigration. } \\
\text { n denoted as } \\
\text { lem for a one }\end{array}$ \\
\hline
\end{tabular}


Figure 1: Media Coverage and Public Opinion on Immigration
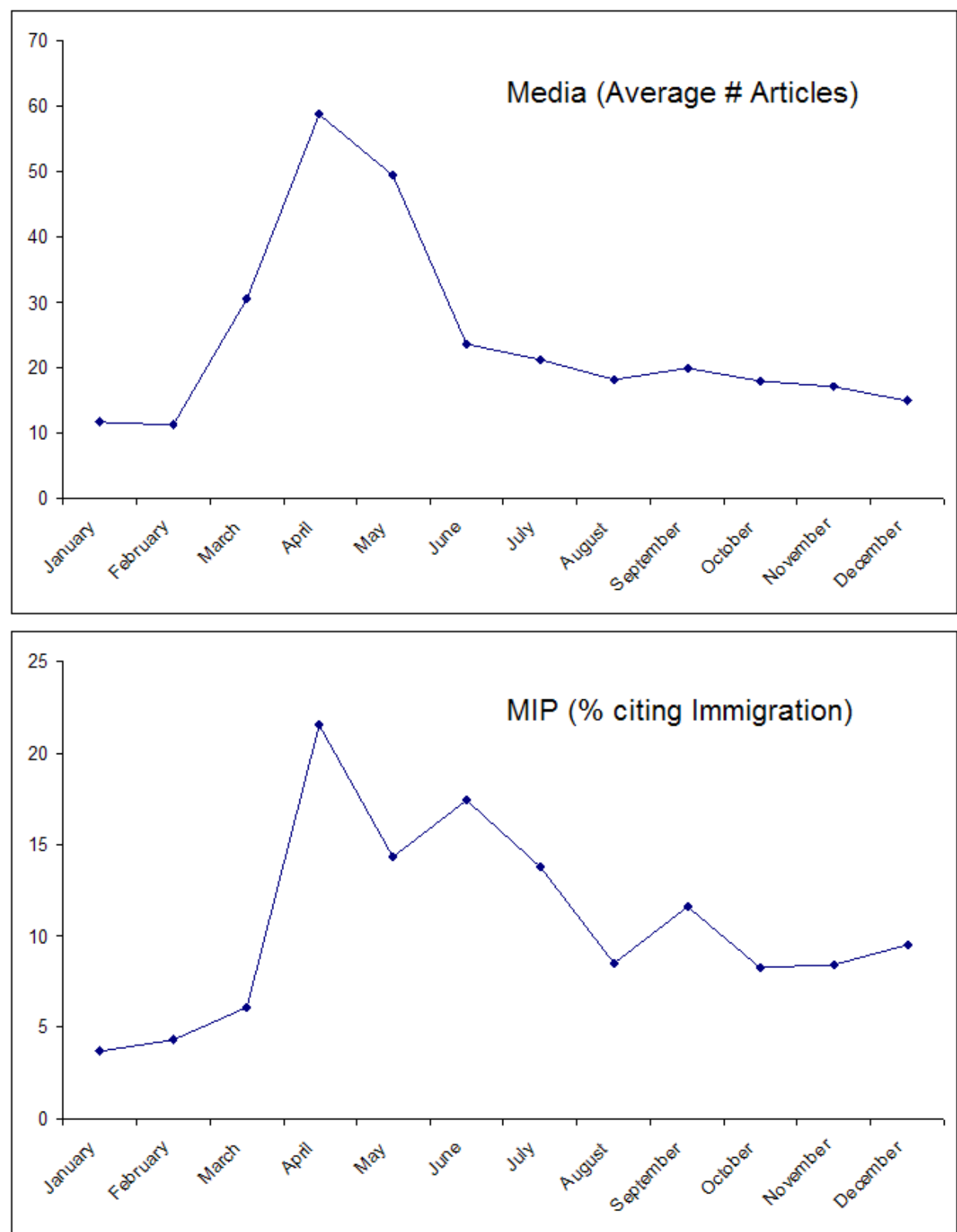
Figure 2: Border and Non-Border Media Outlet Coverage of Immigration

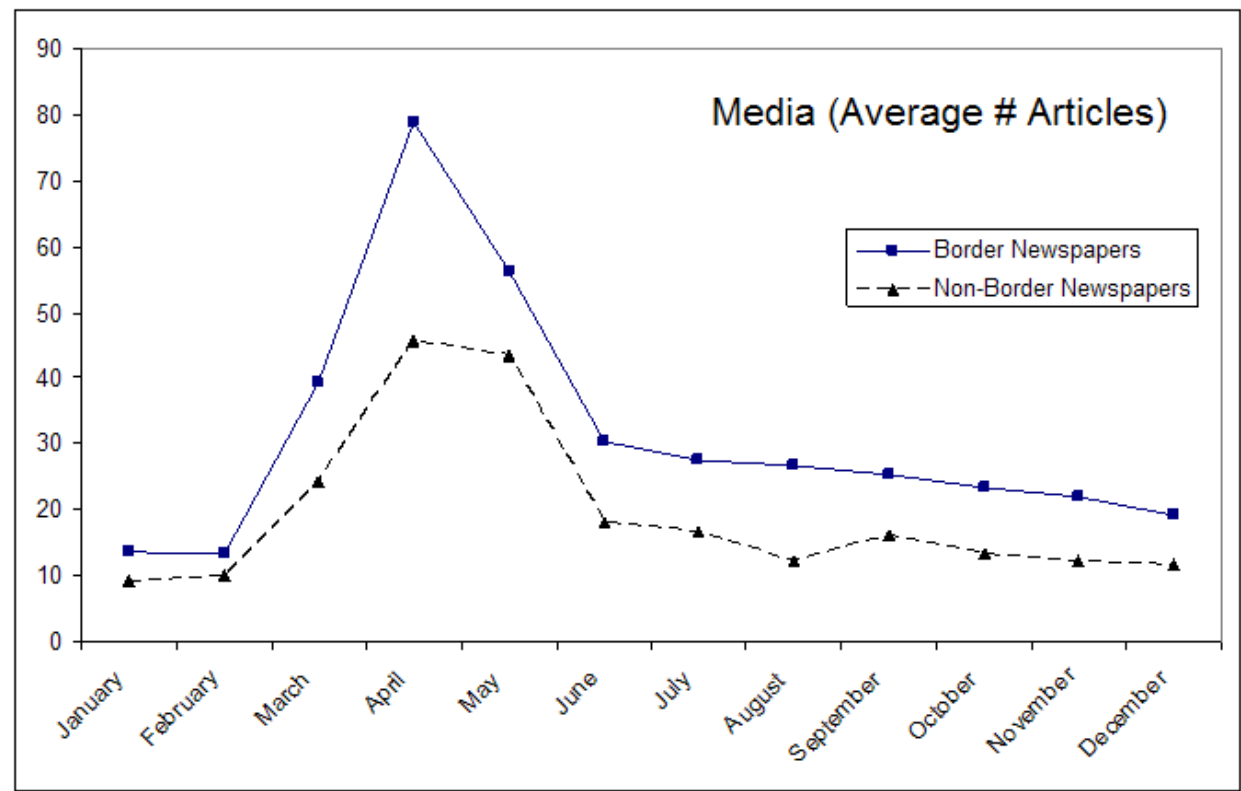

Figure 3: 
Appendix A. Percent of Anglo Respondents Citing Immigration as "Most Important Problem," by Month Immigration: MIP

$\begin{array}{ll}\text { January } & 3.7 \% \\ \text { February } & 4.3 \\ \text { March } & 6.1 \\ \text { April } & 21.5 \\ \text { May } & 14.3 \\ \text { June } & 17.4 \\ \text { July } & 13.8 \\ \text { August } & 8.5 \\ \text { September } & 11.6 \\ \text { October } & 8.3 \\ \text { November } & 8.4 \\ \text { December } & 9.5\end{array}$

